\title{
How a Patent Ductus Arteriosus Effects the Premature Lamb's Ability To Handle Additional Volume Loads
}

\author{
RONALD I. CLYMAN, CHRISTINE ROMAN, MICHAEL A. HEYMANN, AND \\ FRANÇOISE MAURAY \\ Cardiovascular Research Institute and the Departments of Pediatrics, University of California; and Mt. Zion \\ Hospital and Medical Center, San Francisco. California
}

\begin{abstract}
A model of patent ductus arteriosus in premature lambs was created to examine the lamb's ability to handle the volume load imposed by a patent ductus arteriosus and to determine the lamb's ability to handle any additional volume load. Fifteen preterm lambs [133 \pm 2 ( \pm SD) days gestation, term 145 days], whose ductal diameter could be regulated with a mechanical occluder, were studied to determine the independent effects of ductus patency and a saline volume load $(50 \mathrm{ml} / \mathrm{kg}$ over $3 \mathrm{~min})$ on left ventricular output and its distribution. During a saline infusion, preterm lambs with a closed ductus could only increase their stroke volume by $\mathbf{4 0 \%}$ above baseline stroke volume. When challenged with a saline infusion, lambs with an open ductus still were able to increase their stroke volume significantly; the maximal increase in stroke volume during the saline load with the ductus open was $70 \%$ above baseline stroke volume. We hypothesize that the associated reduced left ventricular afterload plays a significant role in the preterm lamb's ability to increase its stroke volume when challenged with a patent ductus arteriosus. Even with a patent ductus arteriosus, the lamb still has the ability to handle additional volume loads. (Pediatr Res 22: 531-535, 1987)
\end{abstract}

\section{Abbreviations}

PDA, patent ductus arteriosus

$L V$, left ventricle

Q $L V$, left ventricular output

Q pulmonary, pulmonary blood flow

$Q$ ductus, ductus arteriosus blood flow

Q systemic, systemic blood flow

$\mathbf{R}$ pulmonary, pulmonary vascular resistance

$R$ systemic, systemic vascular resistance

$\mathbf{R}$ ductus, ductus arteriosus resistance

$R$ total, total resistance

Hbg, hemoglobin

GI, gastrointestinal

The PDA represents a significant stress on the premature cardiovascular system. The extent of this stress depends both on the magnitude of the left to right shunt through the PDA and on the ability of the cardiovascular system to adjust to that shunt.

Received April 27, 1987; accepted June 22, 1987.

Correspondence Ronald I. Clayman, M.D., Box 0544, Room 1403 HSE. University of California, San Francisco, San Francisco, CA 94143.

Supported by grants from the United States Public Health Service SCOR HL 27356 and Program Project Grant HL-24056.
Bishop et al. (1) and Stone et al. (2) used the maximal level of cardiac output reached during a rapid infusion of fluid as a measure of cardiac performance during a volume load. The response to volume loading improves with maturation (3-7). Full-term newborn lambs respond to volume loading with a limited increase in stroke volume, compared with adult sheep. The left ventricle of the full-term newborn lamb is capable of developing greater force than the left ventricle of the preterm lamb (with closed ductus) at comparable filling volume and resistance (6). Several studies have shown that the fetal lamb has a limited ability to increase its stroke volume above its baseline value during an acute volume load (8-12).

The limited ability of the developing left ventricle to increase its output during a volume load is caused by some degree of myocardial immaturity (13) as well as by the high resting output needed to supply the demand for oxygen after delivery (14). The high resting level of performance demanded of the newborn heart may exhaust any reserve pumping capacity. The purpose of our study was both to examine the premature lamb's ability to handle the volume load imposed by a PDA and to see how the presence of a PDA alters the lamb's ability to tolerate any additional volume load.

\section{METHODS}

Preparation. Fifteen mixed breed western time-dated pregnant ewes at 128-133 days gestation (term 145 days) were fasted, but allowed free access to water, for $24-48 \mathrm{~h}$ before surgery. Surgery was performed under epidural anesthesia with $2-4 \mathrm{ml}$ of $1 \%$ tetracaine hydrochloride. Ketamine $(100 \mathrm{mg})$ was administered intravenously every $15-30 \mathrm{~min}$ for sedation. Local anesthesia with $0.25 \%$ lidocaine hydrochloride was used for all fetal incisions. A continuous intravenous infusion of $10 \%$ dextrose in $0.9 \% \mathrm{NaCl}$ was given to the ewe throughout the surgery.

In the ewe, polyvinyl catheters were inserted into the pedal vein and artery and advanced into the inferior vena cava and descending aorta. A hysterotomy was performed, and polyvinyl catheters were inserted into the pedal vein and artery of the fetus and advanced into the inferior vena cava and descending aorta. A left thoracotomy was performed, and the left lung was retracted to.expose the great vessels and the ductus arteriosus. The ductus was dissected from the surrounding tissue, and $10 \%$ buffered formalin was injected into the vessel wall to destroy the muscular layer. Then a mechanical snare (made from a polyvinyl covered cardic catheterization guide wire and a catheter sheath) was looped around the ductus and brought through the fetal chest wall. Catheters were placed in the pulmonary artery and internal mammary artery and vein. In eight fetuses, a catheter was placed in the coronary sinus via the left hemiazygous vein (15). These catheters and the wire were plugged and left in the amniotic 
cavity, whereas the fetal pedal catheters were tunneled subcutaneously to the ewe's flank and secured there in a pouch. The thoracotomy and hysterotomy were closed, and the pregnancy allowed to continue.

After 2 days for surgical recovery, the abdominal incision in the ewe was reopened under epidural anesthesia, and the fetus was delivered onto the maternal abdomen. The fetus was paralyzed with pancuronium bromide ( $0.4 \mathrm{mg}$ intravenously). The trachea was intubated with a $4.5 \mathrm{~F}$ cuffed endotracheal tube, and sheep surfactant was instilled into the trachea $(50 \mathrm{mg}$ surfactant lipid/kg body weight). The sheep surfactant was prepared from lung lavages of healthy adult sheep, as described previously (16). As the surfactant was instilled, the fetus was positioned from side to side to achieve even lung distribution. Then the umbilical cord was ligated, and the lamb was delivered to a warming table and ventilated (in the prone position) with an infant ventilator (Sechrist, Anaheim, CA). Through a peripheral cutdown in the neck (using local anesthesia), additional intravascular catheters were passed into the newborn lamb's LV and right atrium, and an umbilical artery also was cannulated from the umbilical cord. All catheters were placed and secured by $30 \mathrm{~min}$ after delivery.

The initial ventilator settings were peak inspiratory pressure, $28 \mathrm{~cm}$ water; positive end-expiratory pressure, $3 \mathrm{~cm}$ water; inspiratory time, $0.6 \mathrm{~s}$; and respiratory rate, $60 \mathrm{breaths} / \mathrm{min}$. The initial $\mathrm{FiO}_{2}$ was 1.0. After $30 \mathrm{~min}$ stabilization, the ventilator rate was decreased (by increasing the expiratory time) to 30-40 breaths/min. The $\mathrm{PaO}_{2}$ was maintained between 70 and 140 torr by adjusting the $\mathrm{FiO}_{2}$; the $\mathrm{PaCO}_{2}$ was maintained between 25 and 40 torr by adjusting the peak inspiratory pressure. This range of values was chosen to reduce pulmonary vascular resistance, so that any left to right shunt through the ductus arteriosus would be maximized. An intravenous infusion of $5 \%$ dextrose in water at a rate of $5 \mathrm{ml} / \mathrm{kg} / \mathrm{h}$ was begun after delivery. The lambs initially were towel-dried and covered with a plastic sheet to reduce evaporative losses. Rectal temperature was maintained between 38 and $39^{\circ} \mathrm{C}$ with aquamatic $\mathrm{K}$-pads and with radiant heat lamps. Pancuronium bromide was administered as needed to maintain paralysis. For sedation, diazepam (Valium IV, Hoffmann LaRoche, Nutley, NJ), $0.1 \mathrm{mg} / \mathrm{kg}$ intravenously, was given shortly after delivery. Heparinized maternal blood was transfused to replace blood lost from sampling.

Femoral and pulmonary arterial, right atrial, and left ventricular pressures were measured continuously using Beckman pressure transducers (Sensormedics, Anaheim, CA) and a Sensormedics Dynograph R611 multichannel recorder (Anaheim, CA). The signals were averaged electronically to obtain mean pressures.

To measure blood flows, we injected approximately $10^{6}$ radiolabeled $15 \mu \mathrm{m}$ microspheres into the left ventricle while reference blood samples were withdrawn from the ascending and descending aorta (16). Following the experiment, the lamb was sacrificed with $3 \mathrm{ml}$ of Euthanasia- 6 Solution (Veterinary Laboratories, Lenexa, KS), and the position of all catheters and function of the mechanical snare were verified. The organs were removed, weighed, and placed in formalin. They were incinerated at $325^{\circ} \mathrm{C}$ for $72 \mathrm{~h}$, pulverized, and packed into counting vials. The amount of each radionuclide in the organs and reference blood samples was measured with a well-type $\gamma$ scintillation counter and a multiple-channel pulse height analyzer.

QLV and left to right blood flow through the ductus arteriosus (Q ductus) were calculated using the concentration of microspheres in the reference samples, the total number of microspheres recovered from the whole animal, and the total number of microspheres in the lungs (16). An assumed bronchial blood flow of $8 \%$ of $\dot{Q L V}$ was subtracted from the measured lung blood flows. This amount was determined from measurements made in 35 newborn lambs (130-135 days) in which the ductus had been ligated: $8.3 \pm 6.6 \%$, mean $\pm \mathrm{SD}$ (Clyman RI, unpublished observations). We previously have found, using microspheres injected into the inferior vena cava, that right to left shunting of blood through the foramen ovale was less than $4 \%$ of venous return in newborn lambs (130-135 days) 2-10 h following delivery; we have not been able to detect any right to left shunting of blood through the ductus arteriosus (Clyman RI, unpublished observations). Therefore, $\dot{Q}$ pulmonary was considered equal to the $\dot{Q} L V$, and effective $\dot{Q}$ systemic was estimated as the $\dot{Q} L V$ minus the left to right ductal shunt.

Resistances to blood flow were calculated from the pressure and flow measurements. $\mathrm{R}$ pulmonary was calculated by dividing (the mean pulmonary arterial - left ventricular end-diastolic pressure difference) by pulmonary blood flow. R systemic was calculated by dividing (the mean aortic - right atrial pressure difference) by effective systemic blood flow. $\mathrm{R}$ ductus was calculated by dividing (the mean aortic - pulmonary arterial pressure difference) by the ductus arteriosus flow. When the ductus was open, the $\mathrm{R}$ total against which the left ventricle pumps was calculated from the formula for the resistance of two parallel circuits:

$$
\frac{1}{\mathrm{R} \text { total }}=\frac{1}{\text { (R pulmonary }+\mathrm{R} \text { ductus })}+\frac{1}{\mathrm{R} \text { systemic }}
$$

Arterial pH, $\mathrm{PaO}_{2}$, and $\mathrm{PaCO}_{2}$ were measured with a Corning 158 blood gas analyzer (Corning Medical and Scientific, Medfield, MA). Hbg concentrations and oxygen situations were measured with an OSM 2 Hemoximeter (Radiometer, Copenhagen, Denmark).

We calculated oxygen consumption of the left ventricular free wall by multiplying the difference in oxygen contents between the aortic and coronary sinus blood samples by the blood flow to the left ventricular free wall. Although the coronary sinus of the newborn receives small amounts of blood flow from the left atrium and right ventricular free wall, approximately $85 \%$ of coronary sinus flow comes form the left ventricular free wall and septum (17). We calculated the oxygen content of simultaneously drawn ascending aortic and coronary sinus blood samples by the formula:

$$
\begin{gathered}
\left(\% \mathrm{O}_{2} \text { saturation }\right)\left(\mathrm{g} \mathrm{Hbg} \cdot 100 \mathrm{ml}^{-1}\right)\left(1.34 \mathrm{ml} \mathrm{O}_{2} \cdot \mathrm{g} \mathrm{Hbg}^{-1}\right) \\
+\left(\mathrm{PO}_{2} \text { torr }\right)\left(0.003 \mathrm{ml} \mathrm{O}_{2} \cdot 100 \mathrm{ml}^{-1}\right)
\end{gathered}
$$

Experimental protocol. Fifteen lambs $(133.1 \pm 1.8$ days gestation; $3.25 \pm 0.57 \mathrm{~kg}$ ) were used in this experiment, which tested the effect of ductal patency on the cardiovascular response to a rapid expansion of blood volume. We compared the effect of two saline infusions in the same lamb: one was given while the ductus was open, the other while the ductus was closed. In eight lambs, the ductus were closed by $30 \mathrm{~min}$ after delivery, and the lambs were allowed to stabilize for an additional $3 \mathrm{~h}$. At $4.5 \mathrm{~h}$ after delivery, $30 \mathrm{~min}$ following baseline hemodynamic and blood gas measurements, we infused $50 \mathrm{ml} / \mathrm{kg}$ of warmed $\left(39^{\circ} \mathrm{C}\right) 0.9 \% \mathrm{NaCl}$ into the superior vena cava over a 3 -min period. This volume and rate of infusion were chosen because they produced stable left ventricular end diastolic pressure elevations between 18 and 25 torr. We previously had found that this range of left ventricular end diastolic pressures caused a maximal increase in stroke volume in three preterm lambs that had electromagnetic flow transducers around the ascending aorta. This is also the optimal range for full-term newborn lambs $(3,7)$. Left ventricular end diastolic pressure reached its maximum value by $1.5 \mathrm{~min}$ after the start of the infusion and remained stable over the next $1.5 \mathrm{~min}$. Hemodynamic and blood gas measurements were made after $1.5 \mathrm{~min}$ of infusion when the left ventricular end diastolic pressure had plateaued. One $h$ after the volume infusion, the snares were loosened and the ductus opened; the lambs were allowed to stabilize for an additional 2 $\mathrm{h}$ with their ductus open. Seven and one-half $\mathrm{h}$ after delivery ( 3 $h$ after the first volume load), the lambs received a second, identical volume load while their ductus were open. We obtained the same series of measurements as during the first volume load.

In the remaining seven lambs, the order of ductus patency was 
switched. The ductus were open during the first $5.5 \mathrm{~h}$ after delivery. At $5.5 \mathrm{~h}$, the ductus were closed. The first volume load was performed in lambs with open ductus at $4.5 \mathrm{~h}$ after delivery; the second infusion was performed in lambs with closed ductus $7.5 \mathrm{~h}$ after delivery.

We combined the measurements made while the ductus was open in the 15 lambs; similarly, we combined the measurements made when the ductus was closed in the 15 lambs. Therefore, the volume infusion was administered at a mean time of $5.9 \pm$ $1.6 \mathrm{~h}$ after delivery when the ductus was closed and $6.1 \pm 1.6 \mathrm{~h}$ after delivery when the ductus was open $(p=N S)$.

Statistics. We compared measurements by a paired $t$ test. The level of significance was $p<0.05$ (two tailed). The level of significance was adjusted for multiple comparisons of group means with a Bonferroni correction. The data are reported as means $\pm \mathrm{SD}$.

\section{RESULTS}

When the ductus was closed, an infusion of $50 \mathrm{ml} / \mathrm{kg}$ of $0.9 \%$ $\mathrm{NaCl}$ over 3 min produced a significant increase in aortic and pulmonary blood pressures without an associated change in heart rate (Table 1). Despite an increase in left ventricular end diastolic pressure from 4 to $23 \mathrm{~mm} \mathrm{Hg}$, there was only a $40 \%$ increase in stroke volume. Blood flow increased to all the organs except the kidneys and GI tract; arterial blood flow to the liver decreased by $50 \%$ (Table 2). Arterial $\mathrm{PaO}_{2}$ and $\mathrm{PaCO}_{2}$ did not change, but there was a drop in arterial $\mathrm{pH}$ (Table 3 ). There was significant hemodilution with a $34 \%$ decrease in hemoglobin concentration. In addition, left ventricular oxygen consumption rose during the volume infusion $(9.9 \pm 6.6$ versus $13.0 \pm 5.7 \mathrm{ml} \mathrm{O} 2 / \mathrm{min} / 100$ gm, $n=8, p<0.05)$.

In these lambs, when the ductus was opened, the left to right

Table 1. Effect of ductal patency on changes produced by saline infusion $(n=15)$

\begin{tabular}{|c|c|c|c|c|}
\hline & \multicolumn{2}{|c|}{ Ductus closed } & \multicolumn{2}{|c|}{ Ductus open } \\
\hline & Baseline & Infusion & Baseline & Infusion \\
\hline$\overline{\mathrm{Pao}}$ & $58 \pm 6$ & $70 \pm 8^{c *}$ & $46 \pm 5^{d}$ & $57 \pm 9^{c \cdot h}$ \\
\hline$\overline{\mathrm{Ppa}}$ & $34 \pm 8$ & $46 \pm 10^{c}$ & $44 \pm 6^{d}$ & $54 \pm 9^{c \cdot b}$ \\
\hline PLVED & $4 \pm 2$ & $23 \pm 4^{c}$ & $7 \pm 3^{h}$ & $24 \pm 3^{c}$ \\
\hline$\overline{\mathrm{PRA}_{\mathrm{R}}}$ & $2 \pm 2$ & $12 \pm 5^{c}$ & $3 \pm 2$ & $13 \pm 6^{\circ}$ \\
\hline HR & $158 \pm 32$ & $164 \pm 24$ & $175 \pm 39$ & $169 \pm 29$ \\
\hline SV & $0.96 \pm 0.26$ & $1.34 \pm 0.33^{B}$ & $1.36 \pm 0.44^{h}$ & $1.64 \pm 0.36^{B . b}$ \\
\hline Q̈LV & $154 \pm 49$ & $219 \pm 56^{c}$ & $233 \pm 71^{d}$ & $272 \pm 47^{A . b}$ \\
\hline Q́syst & $151 \pm 47$ & $220 \pm 61^{\circ}$ & $117 \pm 33^{a}$ & $166 \pm 47^{c i b}$ \\
\hline $\mathrm{R}$ total & $0.40 \pm 0.12$ & $0.28 \pm 0.09^{c}$ & $0.12 \pm 0.03^{d}$ & $0.09 \pm 0.03^{c . d}$ \\
\hline
\end{tabular}

$\overline{\mathrm{Pa}}, \overline{\mathrm{Pp}}, \overline{\mathrm{PLVED}}, \overline{\mathrm{PR}} \mathrm{A}$ represent mean aortic, mean pulmonary, left ventricular end diastolic, and mean right atrial pressures $(\mathrm{mm} \mathrm{Hg}) ; \mathrm{HR}$ represents heart rate (beat/min); QLV, Qsyst represent left ventricular output and effective systemic blood flow (ml/min $/ \mathrm{kg}$ ); SV represents stroke volume $(\mathrm{ml} / \mathrm{kg}) ; \mathrm{R}$ total represents total resistance against which the left ventficle pumps $(\mathrm{mm} \mathrm{Hg} / \mathrm{ml} / \mathrm{min} / \mathrm{kg})$.

$* A, B, C \quad p<0.01, p<0.001$, and $p<0.0001$, respectively, for differences between baseline and infusion.

$a, b, d p<0.01, p<0.001$, and $p<0.0001$, respectively, for differences between ductus open and ductus closed.

Table 2. Effect of ductal patency on changes produced by saline infusion: organ blood flows $(n=15)$

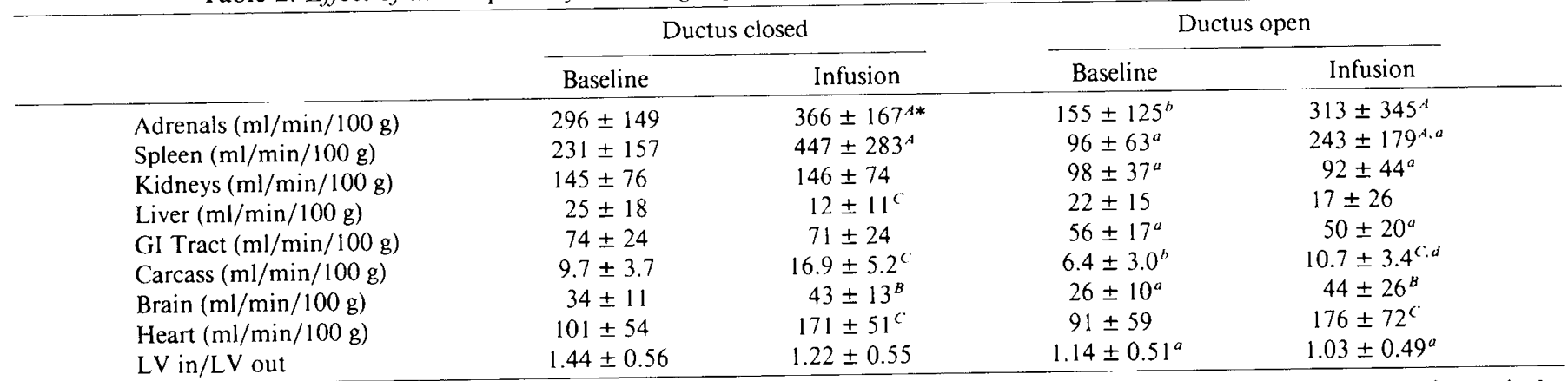

Liver $=$ hepatic arterial blood flow; Carcass $=$ skin, skeletal muscle, and bone; $\mathrm{LV}$ in $/ \mathrm{LV}$ out $=$ blood flow to the inner $1 / 3$ of the left ventricular free wall divided by flow to the outer two-thirds.

$* A, B . C_{p}<0.01, p<0.001$, and $p<0.0001$, respectively, for differences between baseline and infusion.

$a, h, d: p<0.01, p<0.001$, and $p<0.0001$, respectively, for differences between ductus open and ductus closed.

Table 3. Effect of ductal patency on changes produced by saline infusion: arterial blood gas tensions, pH, and Hbg concentration

\begin{tabular}{|c|c|c|c|c|}
\hline & \multicolumn{2}{|c|}{ Ductus closed } & \multicolumn{2}{|c|}{ Ductus open } \\
\hline & Baseline & Infusion & Baseline & Infusion \\
\hline $\begin{array}{l}\mathrm{PaO}_{2}(\mathrm{~mm} \mathrm{Hg}) \\
\mathrm{PaCO}_{2}(\mathrm{~mm} \mathrm{Hg}) \\
\mathrm{pH} \\
\mathrm{Hbg}(\mathrm{g} / 100 \mathrm{ml})\end{array}$ & $\begin{aligned} 96 & \pm 35 \\
30 & \pm 8 \\
7.44 & \pm 0.08 \\
11.7 & \pm 1.5\end{aligned}$ & $\begin{aligned} 104 & \pm 49 \\
33 & \pm 10 \\
7.38 & \pm 0.10^{A} \\
8.7 & \pm 1.4^{C}\end{aligned}$ & $\begin{aligned} & 142 \pm 89^{a *} \\
& 29 \pm 8 \\
& 7.44 \pm 0.07 \\
& 11.4 \pm 1.3 \\
&\end{aligned}$ & $\begin{aligned} 139 & \pm 79 \\
33 & \pm 9^{B} \\
7.35 & \pm 0.08^{B} \\
8.1 & \pm 1.5^{C}\end{aligned}$ \\
\hline
\end{tabular}

$* A, B, C_{p}<0.01, p<0.001$, and $p<0.0001$, respectively, for differences between baseline and infusion.

${ }^{a} p<0.01$ for differences between ductus open and ductus closed. 
shunt through the ductus was $46 \pm 18 \%$ of QLV. There was a significant decrease in baseline aortic blood pressures (diastolic open: $35 \pm 7$ versus closed: $47 \pm 7 \mathrm{~mm} \mathrm{Hg}, p<0.0001$; systolic open: $63 \pm 8$ versus closed: $73 \pm 8 \mathrm{~mm} \mathrm{Hg}, p<0.001)$ and increase in pulmonary and left ventricular end diastolic pressures.

QLV increased by $51 \%$ to accommodate the ductal shunt (Table 1). Because there was no significant increase in heart rate, the increase in QLV was due to an increase in stroke volume. Despite this increase in QLV, effective systemic blood flow decreased by $22 \%$. This was associated with a significant decrease in arterial blood flow to all the organs except the liver and heart. Despite no change in $\mathrm{FiO}_{2}$ or ventilator pressures $\left(\mathrm{FiO}_{2}\right.$ : ductus open $=0.63 \pm 0.28$, closed $=0.62 \pm 0.26$; peak inspiratory pressure; ductus open $=23 \pm 3 \mathrm{~cm} \mathrm{H} \mathrm{H}_{2} \mathrm{O}$, closed $=23 \pm 3 \mathrm{~cm}$ $\mathrm{H}_{2} \mathrm{O}$ ), there was a significant increase in $\mathrm{PaO}_{2}$ when the ductus was open. Left ventricular oxygen consumption was unchanged when the ductus was open (closed: $9.9 \pm 6.6$ versus open: 10.0 $\pm 3.7 \mathrm{ml} \mathrm{O}_{2} / \mathrm{min} / 100 \mathrm{~g}, n=8$ ).

When saline was infused into lambs with an open ductus, the stroke volume was increased by $20 \%$ above baseline values when the ductus was open ( 272 versus $233 \mathrm{ml} / \mathrm{kg} / \mathrm{min}$ ) and by $70 \%$ above baseline values when the ductus was closed (272 versus $154 \mathrm{ml} / \mathrm{kg} / \mathrm{min}$ ). During the infusion, left ventricular end diastolic pressures rose to the same values and Hbg concentrations dropped to the same levels as when the volume infusion was administered while the ductus was closed. Despite these similarities, stroke volume during the volume load was $22 \%$ greater when the ductus was open than when it was closed. If the ductus was open during the volume load, aortic blood pressure and $\mathrm{R}$ total were consistently less than if the ductus was closed.

The changes in organ blood flow that occurred when the volume load was administered while the ductus was open were similar to those that occurred when the ductus was closed. During the volume infusion, there was no significant difference in left ventricular oxygen consumption whether the ductus was closed $(13.0 \pm 5.7 \mathrm{ml} \mathrm{O} 2 / \mathrm{min} / 100 \mathrm{~g})$ or open $\left(12.9 \pm 6.4 \mathrm{ml} \mathrm{O}_{2} / \mathrm{min} /\right.$ $100 \mathrm{~g}, n=8)$.

\section{DISCUSSION}

Our findings during changes in ductus patency were similar to those we and others have reported previously (18-20). When the ductus was open, there was a significant decrease in systemic blood pressures (systolic as well as diastolic) and an increase in left ventricular end diastolic pressure and stroke volume, but no change in heart rate. Despite no change in $\mathrm{FiO}_{2}$ or ventilator pressures, there was a significant increase in $\mathrm{PaO}_{2}$ when the ductus was open. This increase in oxygenation can be explained by the increase in pulmonary blood flow and recirculation of oxygenated arterial blood through atelectatic lungs (21-23). We observed decreased blood flow to the abdominal organs, carcass, and brain, as well as a redistribution of left ventricular blood flow away from the subendocardial muscle. It is unlikely that the decrease in subendocardial flow was caused by the increase in left ventricular end diastolic pressure during ductal opening. We found no change in inner:outer flow ratio during the volume load even though end diastolic pressure was three times greater than with the open ductus alone (Tables 1 and 2). These findings are similar to those found in adult animals, where increases in end diastolic pressure up to $25 \mathrm{~mm} \mathrm{Hg}$ produced negligible changes in subendocardial blood flow in the normally perfused left ventricle (24-26), but decreased subendocardial flow when perfusion pressure was diminished $(25,27)$. The decreased diastolic blood pressure found in lambs with a patent ductus arteriosus may be the primary factor causing the decreased subendocardial perfusion.

During the saline volume infusion, there was no change in heart rate. This has been observed previously during volume infusions in fetal $(10,11)$ and neonatal $(3,4,6)$ lambs. The saline infusion in preterm lambs with closed ductus produced a significant increase in stroke volume. The response differed from that observed in lamb fetuses at the same gestational age (8-12), but was similar to that seen in full-term newborn (6) and 1-wk-old lambs $(3-5,7)$. Although a Frank-Starling relationship has been demonstrated in the fetal lamb (28), challenging the fetus with a volume load only modestly increases stroke volume above baseline measurements $(8-12)$. During the saline infusion, there was a change in the distribution of cardiac output; the liver, kidneys, and gastrointestinal tract received a lower percentage of left ventricular output. This response differs from that seen in the fetal lamb, where there is no change in the distribution of cardiac output during a volume infusion (11).

When the ductus was open, there was an increase in $\dot{Q} L V$, which equalled the maximal output that could be produced with a volume load when the ductus was closed. Despite this, lambs with an open ductus still were able to increase their stroke volume by an additional $20 \%$ when challenged with a saline infusion. Overall, the preterm lambs in this study were able to increase their left ventricular output by $70 \%$ above baseline conditions (with a closed ductus) if the ductus was open during a volume load.

We recently have found that when the ductus is opened in preterm lambs, there is an increase in norepinephrine release from the left ventricle into the blood; this is associated with an increase in left ventricular contractile state (29). Perhaps this increase in contractility when the ductus is open persists during the volume infusion and plays a role in the increased output observed during that condition. However, other studies in adult and newborn animals have not demonstrated an increase in left ventricular contractility during a volume infusion $(5,6,30)$.

We have tried to assess the ability of the premature lamb to tolerate a volume challenge by measuring stroke volume as a function of left ventricular end diastolic pressure. In addition to increasing end diastolic pressure, saline infusions were associated with an increase in arterial pressure. This rise in arterial blood pressure during a volume infusion has been observed in fetal and neonatal lambs (5-11); adult animals show no change in arterial blood pressure $(5,31-33)$, suggesting that the newborn circulation has a reduced capacity to handle a sudden increase in blood volume.

Because arterial pressure increased during the saline infusion and decreased when the ductus was open, it is conceivable that baroreceptor reflexes might become activated during the volume load and prevent cardiac output from increasing when the ductus is closed. Several lines of evidence argue against this hypothesis. First, there were no significant changes in heart rate during the volume infusion, despite the fact that baroreceptors have been shown to be capable of altering fetal heart rate $(34,35)$. Even though baroreceptors can influence fetal heart rate, they have little effect on cardiac output in the fetus (10) and newborn (36). Increases in blood volume in adult animals produce marked increases in cardiac output that are only partially dampened by the baroreceptor system.

The failure of the volume load to cause the same increase in stroke volume in the lambs with closed ductus as in the lambs with open ductus might have been due to the afterload effects of increased vascular resistance and arterial pressure when the ductus was closed. With increases in afterload, stroke volume falls progressively if the preload is held constant $(37,38)$. If the preload is allowed to increase, then increments in afterload, over a significant range, produce only slight reductions in stroke volume. When the normal adult heart has dilated substantially, the ventricle becomes more dependent on afterload for its ejection performance $(37,39,40)$. The preterm lamb's left ventricle has diminished contractility when compared with that of the full term newborn $(5,6,29,41)$. Studies in fetal lambs suggest that the immature myocardium may be quite sensitive to changes in afterload $(5,8,10)$. Although Thornburg and Morton (9) found no effect of afterload on fetal left ventricular performance, more recent studies have found a profound effect of afterload on fetal left ventricular stroke volume, but only at higher filling pressures (Hawkins J, Van Hare G, personal communication) (42). 
Similarly, we found that the premature left ventricle could increase its stroke volume without increasing its energy expenditure (oxygen consumption) when the ductus was open. Although myocardial oxygen consumption depends on both pressure work and stroke volume $(43,44)$, studies in isolated papillary muscle suggest that more oxygen is consumed during force generation than during shortening (45). During the saline volume infusion in our study, both stroke volume and arterial pressure increased; this was associated with significantly increased oxygen consumption. However, when the ductus was opened, stroke volume increased, but arterial pressure decreased; therefore, this condition was not associated with increased oxygen consumption. Finally, during the saline infusion when the ductus was open, the stroke volume was significantly greater than during the infusion with the ductus closed. Despite the increase in output, there was no difference in oxygen consumption between the two conditions. This probably was due to the decrease in arterial pressure when the ductus was open.

Thus the decrease in arterial pressure and total resistance that accompanies opening of the ductus arteriosus may allow the preterm lamb to handle the increased volume load of the left to right shunt and still be able to increase its stroke volume with additional volume loads. As in the fetus, it may be possible to increase cardiac output following volume loading if afterload is kept low (10).

We have found that the preterm lamb has the ability to increase its left ventricular output when challenged with an open ductus, while still retaining a reserve for additional loads. Despite the left ventricular volume reserve, there still are significant decreases in organ blood flow when the ductus is open. As a result, there may be hypoperfusion of certain organs before there are any signs of left ventricular compromise.

Acknowledgments. The authors thank Carl McWaters and Bruce Payne for their help with the microsphere data analysis, Paul Sagan for his skill in preparing and editing this manuscript, Dr. David Teitel for helpful discussions about the project, and Dr. A. M. Rudolph for his encouragement during the project.

\section{REFERENCES}

1. Bishop VS, Stone HL. Guyton AC 1964 Cardiac function curves in conscious dogs. Am J Physiol 207:677-682

2. Stone HL, Bishop VS, Guyton AC 1966 Ventricular function following radioactive damage of the right ventricle. Am J Physiol 211:1209-1213

3. Riemenschneider TA, Allen HD, Mason DT 1986 Maturational changes in myocardial pump performance in newborn lambs. Am Heart J 111:731736

4. Allen HD, Riemenschneider TA, Epstein ML, Mason DT 1986 Hemodynamic responses of the acutely stressed neonatal right ventricle: a maturational study in lambs. Am Heart J 1 11:737-742

5. Romero TE, Friedman WF 1979 Limited left ventricular response to volume overload in the neonatal period: a comparative study with the adult animal. Pediatr Res 13:910-915

6. Baylen BG, Ogata H, Ikegami M. Jacobs H, Jobe A, Emmanouilides GC 1986 Left ventricular performance and contractility before and after volume infusion: a comparative study of preterm and full term newborn lambs. Circulation 73:1042-1049

7. Klopfenstein HS, Rudolph AM 1978 Postnatal changes in the circulation and responses to volume loading in sheep. Circ Res 42:839-845

8. Thornburg KL, Morton MJ 1983 Filling and arterial pressures as determinants of RV stroke volume in the sheep fetus. Am J Physiol 244:H656-H663

9. Thornburg KL, Morton MJ 1986 Filling and arterial pressures as determinants of left ventricular stroke volume in fetal lambs. Am J Physiol 251:H961H968

10. Gilbert RD 1982 Effects of afterload and baroreceptors on cardiac function in fetal sheep. J Dev Physiol 4:299-309

11. Gilbert RD 1980 Control of fetal cardiac output during changes in blood volume. Am J Physiol 238:H80-H86

12. Heymann MA, Rudolph AM 1973 Effects of increasing preload on right ventricular output in fetal lambs in utero. Circulation 48:37(abstr)

13. Friedman WF 1972 The intrinsic physiologic properties of the developing heart. Prog Cardiovasc Dis 15:87-111

14. Lister G, Walter TK, Versmold HT, Dallman PR, Rudolph AM 1979 Oxygen delivery in lambs: Cardiovascular and hematologic development. Am J Physiol 237:H668-H675
15. Fisher DJ, Heymann MA, Rudolph AM 1981 Myocardial consumption of oxygen and carbohydrates in newborn sheep. Pediatr Res 15:843-846

16. Durand DJ, Clyman RI, Heymann MA, Clements JA, Mauray F. Kitterman JA. Ballard P 1985 Effects of a protein free, synthetic surfactant on the survival and pulmonary function of preterm lambs. J Pediatr 107:775-780

17. Fisher DJ. Heymann MA. Rudolph AM 1980 Myocardial oxygen and carbohydrate consumption in fetal lambs in utero and in adult sheep. Am J Physiol 238:H399-H405

18. Clyman RI, Mauray F, Heymann MA, Roman C Cardiovascular effects of a patent ductus arteriosus in preterm lambs with respiratory distress. J Pediatr (in press)

19. Baylen BG, Ogata H. Ikegami M. Jacobs H. Jobe A. Emmanouilides GC 1983 Left ventricular performance and regional blood flows before and after ductus arteriosus occlusion in premature lambs treated with surfactant. Circulation 67:837-843

20. Baylen BG, Ogata H, Oguchi K. Ikegami M, Jacobs H, Jobe A, Emmanouilides GC 1985 The contractility and performance of the preterm left ventricle before and after early patent ductus arteriosus occlusion in surfactant treated lambs. Pediatr Res 19:1053-1058

21. Dawes GS. Mott JC. Widdicombe JG 1955 The patency of the ductus arteriosus in newborn lambs and its physiological consequences. J Physiol 128:361383

22. Born GVR, Dawes GS, Mott JC. Rennick BR 1955 The relief of central cyanosis caused by pulmonary arteriovenous shunts by construction of an artificial ductus arteriosus. J Physiol 130:167-190

23. West JB 1977 State of the art: Ventilation-perfusion relationships. Am Rev Respir Dis 116:919-943

24. Baird RJ, Adiseshiah M 1976 The response of diastolic myocardial tissue pressure and regional coronary blood flow to increased preload from blood, colloid, and crystalloid. Surgery 79:644-651

25. Kjekshus JK 1973 Mechanism for flow distribution in normal and ischemic myocardium during increased ventricular preload in the dog. Circ Res 33:489-499

26. Allard JR, Gertz EW, Verrier ED, Bristow JD. Hoffman JIE 1983 Role of the pericardium in the regulation of myocardial blood flow and its distribution in the normal and acutely failing left ventricle of the dog. Cardiovasc Res 10:595-603

27. Dunn RB Griggs DM Jr. 1983 Ventricular filling pressure as a determinant of coronary blood flow during ischemia. Am J Physiol 244:H429-436

28. Kirkpatrick SE, Pitlick PT, Naliboff J, Friedman WF 1976 Frank Starling relationship as an important determinant of fetal cardiac output. Am J Physiol 231:494-500

29. Clyman RI, Teitel D, Padbury J, Roman C, Mauray F 1987 PDA: role of catecholamines and increased contractile state. Clin Res 35:202(abstr)

30. Mahler F. Covell JW, Ross J Jr. 1975 Systolic pressure-diameter relations in the normal conscious dog. Cardiovasc Res 9:447-455

31. Prather JW, Taylor AE, Guyton AC 1969 Effect of blood volume, mean circulatory pressure and stress relaxation on cardiac output. Am J Physiol 216:467-472

32. Richardson TW, Stallings O, Guyton AC 1961 Pressure volume curves in live intact dogs Am J Physiol 201:471-474

33. Warren JV, Brannon ES. Weens HS, Stear EA 1948 Effect of increasing the blood volume and right atrial pressure on the circulation of normal subjects of intravenous infusions. Am J Med 4:193-198

34. Shinebourne EA, Vapaavuori EK, Williams RL, Heymann MA, Rudolph AM 1972 Development of baroreflex activity in unanesthetized fetal and neonatal lambs. Circ Res 31:710-718

35. Maloney JE, Cannata J, Dowling MH, Else W, Ritchic B 1977 Baroreflex activity in conscious fetal and newborn lambs. Biol Neonate 31:340-350

36. Downing SE, Milgram EA, Halloran KH 1971 Cardiac responses to autonomic nerve stimulation during acidosis and hypoxia in the lamb. Am J Physiol 220:1956-1963

37. MacGregor DC, Covell JW, Mahler F. Dilly RB, Toss J Jr. 1974 Relations between afterload, stroke volume, and descending limb of Starling's curve. Am J Physiol 227:884-890

38. Myhre ES, Johansen A. Bjфrnstad J, Piene H 1986 The effect of contractility and preload on matching between the canine left ventricle and afterload. Circulation 73:161-171

39. Ross JR Jr., Covell JW, Sonnenblick EH 1966 Contractile state of the heart characterized by force velocity in variably afterloaded and isovolumic beats. Circ Res 18:149-163

40. Ross JR Jr. 1976 Afterload mismatch and preload reserve: a conceptual framework for the analysis of ventricular function. Prog Cardiovasc Dis $18: 255-264$

41. Berman W Jr.. Musselman J 1979 Myocardial performance in the newborn lamb. Am J Physiol 237:H66-H70

42. Kuipers JRG, Sidi D. Heymann MA, Rudolph AM 1984 Effects of nitroprusside on cardiac function, blood flow distribution and oxygen consumption in the conscious young lamb. Pediatr Res 18:618-626

43. Vinten-Johansen J, Duncan HW, Finkenberg JG, Hume MC, Robertson JM, Barnard RJ, Buckberg GD 1982 Prediction of myocardial oxygen requirements by indirect indices. Am J Physiol 243:H862-H868

44. Weber KT, Janicki JS 1977 Myocardial oxygen consumption: the role of wall force and shortening. Am J Physiol 233:H421-H430

45. Parmley WW. Tyberg JV 1976 Determinants of myocardial oxygen demand. In: Yu PN, Goodwin JF (eds) Progress in Cardiology, Vol 5. Lea and Febiger. Philadelphia, pp 19-36 